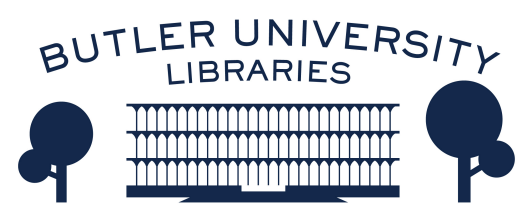

Journal of Hindu-Christian Studies

Volume 15

Article 17

January 2002

\title{
Book Review: "Jules Monchanin (1895-1957) as Seen from East and West, volumes 1 and 2"
}

Judson B. Trapnell

Follow this and additional works at: https://digitalcommons.butler.edu/jhcs

Part of the Religion Commons

\section{Recommended Citation}

Trapnell, Judson B. (2002) "Book Review: "Jules Monchanin (1895-1957) as Seen from East and West, volumes 1 and 2"," Journal of Hindu-Christian Studies: Vol. 15, Article 17.

Available at: https://doi.org/10.7825/2164-6279.1284

The Journal of Hindu-Christian Studies is a publication of the Society for Hindu-Christian Studies. The digital version is made available by Digital Commons @ Butler University. For questions about the Journal or the Society, please contact cbauman@butler.edu. For more information about Digital Commons @ Butler University, please contact digitalscholarship@butler.edu. 
disciples on the night of instituting the sacrament.

According to Jacob Kavunkal, "revisioning of Christian identity" across the religious borders may be possible if we take seriously "the fragrance of Jesus Christ" as the paradigm for contemporary mission.[315]. We are aware that the Son of God did not stay in the safe immunity of his heaven, remote from human alienation of oneself from the Creator, one's neighbour and the rest of creation. Jesus Christ emptied himself of his glory and humbled himself to serve the humanity like a slave and to die on the cross for their redemption. The values of the kingdom, which he shared through his teachings, are all perfect human values. He penetrated deeply into our humanness. $\mathrm{He}$ became friend of sinners and the dropouts of society. He touched the untouchables. Crossing the borders for him was total identification of love. As a matter of fact, "Christian history is replete with examples of momentous border crossings" since its inception, as rightly observed by Isaac Padinjarekuttu. [326]

Fourth, crossing across interdisciplinary sciences is essential in our time to protect humane values of our civilization. For example, crossing the borders between religion and science cannot be any longer an option, but an obligation. Otherwise, in the name of scientific research, "the rightful human dignity and important human concerns" are likely to be "mortgaged by developments in genome research and genetic engineering." [347]

To those committed to one religion or tradition, it may not be easy to cross their borders and to identify themselves with people of other traditions and beliefs. But, in order to be enriched in our lives we need to take the difficult path of reconciliation, by dying to ourselves. In the words of Father Francis D'Sa, "...crossing is basically a cross, that is a sign of life, that makes us give up the old and enter the new, that makes us go through death to life." [407]. In other words, though the cross of Christ portrays the most hopeless situation in human viewpoint, it has become the very foundation for our hope and faith.

Crossing the Borders calls the readers to take the risk of losing one's identity and to transcend the most intransigent walls erected in our society in the name of religion and culture. I trust that many readers of this volume would find it a helpful tool for inspiring them to cross the many barriers, dividing the humanity.

I congratulate the editors, authors of various chapters and the publisher on bringing out this timely contribution, which promotes shalom in the beginning of the 21st Century.

J.T.K. Daniel, Ph. D., Former Principal of Serampore College

\section{Jules Monchanin (1895-1957) as Seen from East and West, volumes 1 and 2. English translation edited by Thomas Matus, O.S.B. Cam. and Sister Sarananda, O.S.B. Delhi: ISPCK and Saccidananda Ashram, 2001, 200 and 153 pp.}

THESE TWO VOLUMES offer a detailed and intriguing portrait of a 20th century Western pioneer in the Hindu-Christian dialogue who, though perhaps less well known than his successors, nevertheless merits both scholarly attention and critical appraisal. 
Jules Monchanin, S.A.M. was a Catholic priest of the diocese of Lyon, France during the creative theological period there between the two world wars. A friend of Henri de Lubac and Louis Massignon, Monchanin became a well-respected figure among French theologians, missionaries, and Indologists (Vol. I, 31-45). His attraction to India began in his teens, eventually becoming a call to which he committed himself at age 37 in response to a serious illness. During the subsequent seven years of waiting for permission to fulfill this vocation, he joined the Societe des auxiliaires des missions (S.A.M.) founded by Fr. Vincent Lebbe, immersed himself in the study of Sanskrit, and intensified his study of Indian culture. Finally in 1939, he received approval from the Bishop of Tiruchirappalli in Tamil Nadu to live an apostolate of contemplative prayer and study that was fully adapted to India. In their final meeting, de Lubac shared with his friend a task that would define not only Monchanin's vocation but also that of his colleagues and fellow emigres Henri Le Saux and Bede Griffiths: "to rethink everything in the light of theology and to rethink theology through mysticism, freeing it from everything incidental and regaining, through spirituality alone, everything essential." Monchanin also recalled from this visit an important insight for all who seek to do Christian theology in a non-Western setting: "He believes that it is in coming into contact with India that I will be able to rework theology much better than by going into theological problems in themselves" (Vol. I, 63).

The break from his personal and professional life in France was almost total; God seemed to have answered his prayer for a "violent uprooting" (Vol. I, 136). Between 1939 and 1950, Monchanin accepted appointments in several small villages in the diocese, living a hidden life devoted to serving his parishioners as well as to contemplation and study. Nevertheless, except during the Second World War, he maintained contact with de Lubac and others in France, connections he also rekindled during a visit to France with his bishop in 1946 where he shared his insights on India through public lectures. In 1948 he was joined in his work by another French priest, Henri Le Saux, O.S.B. with whom he founded Saccidananda Ashram at Shantivanam, fulfilling their mutual dream to renew the indigenous church through a contemplative community that was at once fully Christian and fully Indian (Vol. II, pp. 75-84). It was Monchanin who initiated Le Saux into a dialogue with Hindu spirituality and ashrams, after which the disciple would exceed his master's sense of caution and orthodoxy (Vol. I, 141).

The final sèven years of Monchanin's life were enriched by increased recognition among Indian Christians but were also strained by the apparent failure of the ashram to attract lasting vocations. Like Charles de Foucauld, he wished to be a seed that would die in foreign soil in order to some day give rise to new life (Vol. II, 4647, cf. Jn. 12.24)--a wish that his successor at Saccidananda Ashram, Bede Griffiths, would claim was fulfilled (Vol. I, back cover). Raimon Panikkar, who debated with Monchanin in the 1950s about the meaning for India of a Trinitarian doctrine phrased in Greek categories, characterizes Monchanin's legacy as follows: "We well might have gone beyond Monchanin's conceptions but it would not have been done without his contribution" (Vol. I, 189).

These two volumes present the talks given at two colloquia on the life and thought of Jules Monchanin held respectively in Lyon-Fleurie, France and in Shantivanam-Tannirpalli, India in 1995 to commemorate the centenary of his birth. The two volumes reflect their distinct cultural contexts and effectively present the two parts of Monchanin's life. The texts are valuable as sources on Monchanin's life and writings, as interpretations and assessments of his theological and missionary efforts, and as a model for the scholarly study of those who have immersed themselves in 
unfamiliar cultures and religions in order to learn about them firsthand, initiating thereby as well a dialogue with their culture of origin.

The first volume contains eighteen essays, primarily by French Catholics, most of them of a scholarly nature, that cover the range of Monchanin's life from his formation in Lyon through his years on India. Grouped in thematic sections, the essays describe the details of his professional activities in France, the key themes of his theology, and the India he encountered in the 1940s and 1950s. Included as well are comparative and appreciative essays that highlight his impact on other, perhaps better known figures (de Lubac, Le Saux, Griffiths), and laud his contribution to French and Indian theology as an incisive thinker but also as a Christlike human being.

The second volume, as described by Thomas Matus in his preface, balances scholarly essays like those in the first volume with a richer selection of personal remembrances and with something of the spirit of prayerful sharing at the second colloquium held at the ashram Monchanin co-founded. The scholarly essays, written primarily by Indian Christians, discuss Christian ashram life and monasticism in India and offer critical assessments of Monchanin's interreligious experience and theology, followed by some discussion and response among the participants. One is again left with a portrait of this pioneer in dialogue that is at once poignant and thought-provoking. Michael Amaladoss, SJ, affirming Monchanin's sense that only Indians will be able to integrate Christianity and Hinduism, concludes, "The great love and respect that Monchanin had for Indian religious tradition is certainly an inspiration to us Indians. His sacrifical efforts to realize that vision is a continuing challenge to us and to people everywhere to discern and follow our own way of realizing that communion, of which the Trinity continues to remain the inspiration and the force" (Vol. II, 118, 126).

Both volumes are available in the U.S. from Osage Monastery, 18701 W. Monastery Road, Sand Springs, OK 74063.

Judson B. Trapnell

Former Assistant Professor

College of St. Benedict and

St. John's University

\section{Rediscovering God with Transcendental Argument: A Contemporary Interpretation of Monistic Kashmiri Saiva Philosophy. David Peter Lawrence. Albany: State University of New York Press, 1999, 306 pp.}

LAWRENCE'S WORK is a valuable
contribution toward the comparative
philosophical/theological side of the work of
the Society for Hindu-Christian Studies. It
should broaden a knowledge and
understanding of a most important school of
tenth-century Hindu thinkers, the
Pratyabhijna [recognition] system of the
Kashmiri Saiva thinkers Utpaladeva and
Abhinavagupta. Beyond this, however, as a work of scholarship, Rediscovering God is state of the art for four reasons.

First, it is a superb contemporary exposition of the neglected Saiva theistic metaphysics of Utpaladeva (c. 900-950) and Abhinavagupta (c. 975-1025). Jose Pereira has called the Kashmiri Saiva thought of Abhinavagupta "the greatest and most consistent of the Difference-in-Identity theologies." An informed understanding of this tradition will help to correct an over- 